\title{
Safety and efficacy of vismodegib in patients aged $\geq 65$ years with advanced basal cell carcinoma
}

\author{
Anne Lynn S. Chang ${ }^{1}$, Karl D. Lewis², Sarah T. Arron ${ }^{3}$, Michael R. Migden ${ }^{4}$, James \\ A. Solomon ${ }^{5,6,7}$, Simon Yoo, Bann-Mo Day ${ }^{9}$, Edward F. McKenna9, Aleksandar \\ Sekulic ${ }^{10}$ \\ ${ }^{1}$ Stanford University, Redwood City, CA, USA \\ ${ }^{2}$ University of Colorado, Aurora, CO, USA \\ ${ }^{3}$ University of California, San Francisco, San Francisco, CA, USA \\ ${ }^{4}$ The University of Texas MD Anderson Cancer Center, Houston, TX, USA \\ ${ }^{5}$ Ameriderm Research, Ormond Beach, FL, USA \\ ${ }^{6}$ University of Central Florida, Orlando, FL, USA \\ ${ }^{7}$ University of Illinois, Urbana, IL, USA \\ ${ }^{8}$ Northwestern University, Chicago, IL, USA \\ ${ }^{9}$ Genentech, Inc., South San Francisco, CA, USA \\ ${ }^{10}$ Mayo Clinic, Scottsdale, AZ, USA \\ Correspondence to: Karl D. Lewis, email: Karl.Lewis@ucdenver.edu \\ Keywords: basal cell carcinoma, vismodegib, age, Hedgehog pathway inhibitor, locally advanced basal cell carcinoma \\ Received: March 21,2016 Accepted: September 24, $2016 \quad$ Published: October 14, 2016
}

\section{ABSTRACT}

Because many patients with unresectable basal cell carcinoma (BCC) are aged $\geq 65$ years, this study explores the efficacy and safety of vismodegib in these patients with locally advanced (la) or metastatic $(m)$ basal cell carcinoma (BCC) in the ERIVANCE BCC trial and the expanded access study (EAS).We compared patients aged $\geq 65$ years to patients aged $<65$ years taking vismodegib $150 \mathrm{mg} /$ day, using descriptive statistics for response and safety. Patients aged $\geq 65$ years (laBCC/mBCC) were enrolled in ERIVANCE BCC (33/14) and EAS (27/26). Investigator-assessed best overall response rate in patients $\geq 65$ and $<65$ years was $46.7 \% / 35.7 \%$ and $72.7 \% / 52.6 \%$ (laBCC/mBCC), respectively, in ERIVANCE BCC and $45.8 \% / 33.3 \%$ and $46.9 \% / 28.6 \%$, respectively, in EAS. These differences were not clinically meaningful. Safety was similar in both groups, although those aged $\geq 65$ years had a higher percentage of grade 3-5 adverse events than those aged $<65$ years. Vismodegib demonstrated similar clinical activity and adverse events regardless of age.

\section{INTRODUCTION}

Therapeutic options are limited for patients with advanced basal cell carcinoma (aBCC), including locally advanced (laBCC) or metastatic (mBCC) disease. Aberrant activation of the Hedgehog pathway has been identified as a key driver in the pathogenesis of BCC, and was first described in patients with basal cell carcinoma nevus syndrome (BCCNS) [1, 2]. Vismodegib, the first Hedgehog pathway inhibitor to be approved by the US Food and Drug Administration (FDA), is indicated for patients who have $\mathrm{aBCC}$ that has recurred after surgery or who are not candidates for surgery and radiation [3]. In the pivotal aBCC study (ERIVANCE BCC), vismodegib demonstrated an objective response rate of $43 \%$ in patients with laBCC and $30 \%$ in patients with $\mathrm{mBCC}$ by independent review [3].

Patients aged $\geq 65$ years have had longer exposure to ultraviolet light and may have more difficulty identifying new or changing skin lesions because of the presence of other age-related changes. For example, patients in this age group are more likely than younger patients to have declining eyesight or age-related skin changes such as actinic lentigo, seborrheic keratosis, or actinic keratosis 
[4]. Therefore, older patients are more likely to present with multiple lesions or with more advanced or neglected lesions than younger patients $[5,6]$. Furthermore, patients aged $\geq 65$ years may be more vulnerable to adverse events (AEs) from anticancer treatments because of comorbid medical conditions, age-related reductions in organ or cognitive function, and reduced physiologic reserves, resulting in a shift in the overall benefit-risk ratio of treatment [7].

Here, we present the efficacy and safety of vismodegib in patients aged $\geq 65$ years with aBCC compared with younger patients who were all enrolled in the ERIVANCE BCC pivotal trial [3] and the US expanded access study (EAS) [8].

\section{RESULTS}

\section{Patients}

The ERIVANCE BCC trial enrolled 104 patients, including $71(68 \%)$ and $33(32 \%)$ with laBCC and with $\mathrm{mBCC}$, respectively; 33 (46\%) patients with $\mathrm{laBCC}$ and
$14(42 \%)$ patients with $\mathrm{mBCC}$ were aged $\geq 65$ years. The EAS study enrolled 119 patients, of whom $62(53 \%)$ and $57(47 \%)$ had laBCC and mBCC, respectively; 27 $(43 \%)$ patients with laBCC and $26(46 \%)$ patients with $\mathrm{mBCC}$ were aged $\geq 65$ years. Apart from age, baseline demographic and disease characteristics were generally similar between patients aged $\geq 65$ years and those aged $<65$ years (Table 1). Concomitant medical conditions (e.g., hypertension, hyperlipidemia) were more frequent in patients aged $\geq 65$ years than in younger patients. Basal cell carcinoma nevus syndrome, headache, depression, insomnia, and seasonal allergies were more common in younger patients.

\section{Treatment exposure}

Because of early termination of the EAS study, the median duration of treatment with vismodegib was shorter in the EAS study than in the ERIVANCE BCC study. Median treatment durations in patients with aBCC aged $\geq 65$ years and $<65$ years were 9.2 and 10.2 months in ERIVANCE BCC, respectively, and 5.5 and

Table 1: Patient demographics and baseline disease characteristics

\begin{tabular}{|c|c|c|c|c|c|c|c|c|}
\hline & \multicolumn{4}{|c|}{ ERIVANCE BCC $(N=104)$} & \multicolumn{4}{|c|}{$\operatorname{EAS}(N=119)$} \\
\hline & \multicolumn{2}{|c|}{ laBCC } & \multicolumn{2}{|c|}{$\mathrm{mBCC}$} & \multicolumn{2}{|c|}{ laBCC } & \multicolumn{2}{|c|}{$\mathrm{mBCC}$} \\
\hline & $\begin{array}{l}\geq 65 \text { years } \\
\quad(n=33)\end{array}$ & $\begin{array}{c}<65 \text { years } \\
(n=38)\end{array}$ & $\begin{array}{l}\geq 65 \text { years } \\
\quad(n=14)\end{array}$ & $\begin{array}{c}<65 \text { years } \\
(n=19)\end{array}$ & $\begin{array}{l}\geq 65 \text { years } \\
(n=27)\end{array}$ & $\begin{array}{c}<65 \text { years } \\
(n=35)\end{array}$ & $\begin{array}{l}\geq 65 \text { years } \\
(n=26)\end{array}$ & $\begin{array}{c}<65 \text { years } \\
(n=31)\end{array}$ \\
\hline $\begin{array}{l}\text { Median age, years } \\
\text { (range) }\end{array}$ & $75.0(65-101)$ & $50.5(21-62)$ & $71.5(66-92)$ & $53(38-64)$ & $77(67-92)$ & $53(26-63)$ & $71.5(65-100)$ & $55(24-63)$ \\
\hline Female, $n(\%)$ & $15(45.5)$ & $17(44.7)$ & $4(28.6)$ & $5(26.3)$ & $4(14.8)$ & $15(42.9)$ & $4(15.4)$ & $8(25.8)$ \\
\hline White, $n(\%)$ & $33(100.0)$ & $38(100.0)$ & $14(100.0)$ & $19(100.0)$ & $27(100.0)$ & $33(94.3)$ & $25(96.2)$ & $31(100.0)$ \\
\hline \multicolumn{9}{|l|}{ ECOG PS, $n(\%)$} \\
\hline 0 & $22(66.7)$ & $29(76.3)$ & $5(53.7)$ & $8(42.1)$ & $12(44.4)$ & $27(77.1)$ & $14(53.8)$ & $16(51.6)$ \\
\hline 1 & $7(21.2)$ & $8(21.1)$ & $9(64.3)$ & $10(52.6)$ & $12(44.4)$ & $7(20.0)$ & $10(38.5)$ & $12(38.7)$ \\
\hline 2 & $4(12.1)$ & $1(2.6)$ & 0 & $1(5.3)$ & $3(11.1)$ & $1(2.9)$ & $2(7.7)$ & $3(9.7)$ \\
\hline \multicolumn{9}{|c|}{ No. of target lesions, $n(\%)$} \\
\hline 1 & $26(78.8)$ & $22(57.9)$ & $4(28.6)$ & $5(26.3)$ & $16(59.3)$ & $18(51.4)$ & $12(46.2)$ & $12(38.7)$ \\
\hline 2 & $5(15.2)$ & $7(18.4)$ & $2(14.3)$ & $2(10.5)$ & $6(22.2)$ & $7(20.0)$ & $4(15.4)$ & $6(19.4)$ \\
\hline$\geq 3$ & $2(6.1)$ & $9(23.7)$ & $8(57.2)$ & $12(63.3)$ & $5(18.5)$ & $10(28.5)$ & $10(38.5)$ & $13(42.0)$ \\
\hline \multicolumn{9}{|c|}{ Prior treatment, $n(\%)$} \\
\hline Surgery & $27(81.8)$ & $35(92.1)$ & $14(100.0)$ & $18(94.7)$ & $25(92.6)$ & $32(91.4)$ & $25(96.2)$ & $29(93.5)$ \\
\hline Radiotherapy & $13(39.4)$ & $9(23.7)$ & $9(64.3)$ & $10(52.6)$ & $11(40.7)$ & $9(25.7)$ & $18(69.2)$ & $17(54.8)$ \\
\hline $\begin{array}{l}\text { Systemic } \\
\text { therapy }\end{array}$ & $2(6.1)$ & $6(15.8)$ & $2(14.3)$ & $8(42.1)$ & $7(25.9)$ & $4(11.4)$ & $7(26.9)$ & $13(41.9)$ \\
\hline $\begin{array}{l}\text { Surgery } \\
\text { contraindicated, } \\
n(\%)\end{array}$ & $14(42.4)$ & $29(76.3)$ & NA & NA & $18(66.7)$ & $17(48.6)$ & NA & NA \\
\hline
\end{tabular}

BCCNS = basal cell carcinoma nevus syndrome; EAS = expanded access study; ECOG PS = Eastern Cooperative Oncology Group performance status; laBCC = locally advanced basal cell carcinoma; $\mathrm{mBCC}=$ metastatic basal cell carcinoma; NA = not applicable. 
5.4 months in the EAS, respectively. Information on cumulative exposure to study treatment is presented in Table 2.

\section{Best overall response rate}

Clinical activity was observed across all cohorts in both studies. In the ERIVANCE BCC study, the investigator-assessed best overall response rate (BORR) was $46.7 \%$ (95\% confidence interval [CI] 28.3-65.7\%) and $72.7 \%$ (54.5-86.7\%) in patients with laBCC aged $\geq 65$ and $<65$ years, respectively. In the EAS, the BORR was $45.8 \%(25.6-67.2 \%)$ and $46.9 \%(29.1-65.3 \%)$ in patients with laBCC aged $\geq 65$ and $<65$ years, respectively. Among patients with $\mathrm{mBCC}$, the BORR was $35.7 \%(95 \%$ CI $12.8-64.9 \%)$ and $52.6 \%(95 \%$ CI $28.9-75.6 \%)$ in patients aged $\geq 65$ and $<65$ years, respectively, in the ERIVANCE BCC study, and 33.3\% (95\% CI $13.3-59 \%$ ) and $28.6 \%$ (95\% CI $11.3-52.2 \%$ ) in patients aged $\geq 65$ and $<65$ years, respectively, in the EAS (Table 3). Representative examples of individual patient responses are shown in Figure 1.

\section{Safety}

Within each trial, vismodegib demonstrated a safety profile in patients aged $\geq 65$ years similar to that observed in younger patients (Table 4). The most frequent AEs in patients aged $\geq 65 v s .<65$ years in ERIVANCE BCC and the EAS were muscle spasms ( $64 \%$ vs. $72 \%$ and $70 \%$ vs. $73 \%$, respectively), dysgeusia ( $51 \%$ vs. $51 \%$ and $70 \%$ vs. $73 \%$, respectively), and alopecia ( $49 \%$ vs. $75 \%$ and $55 \%$ vs. $61 \%$, respectively). Grade 3-5 AEs in patients aged $\geq 65$ vs. $<65$ years occurred in $51 \%$ vs. $35 \%$ of patients in ERIVANCE BCC and $25 \%$ vs. $21 \%$ of patients in EAS, respectively. Similarly, AEs leading to treatment discontinuation occurred in $15 \%$ vs. $11 \%$ and $11 \%$ vs. $2 \%$ of patients aged $\geq 65 v s$. $<65$ years in ERIVANCE BCC and EAS, respectively. Although numerical differences in the incidence of AEs were observed across cohorts, no consistent trends were observed across studies. No new safety signals were identified.

\section{DISCUSSION}

This analysis of the ERIVANCE BCC study and the EAS evaluated the efficacy and safety of vismodegib in patients with $\mathrm{aBCC}$ aged $\geq 65$ years compared with those aged $<65$ years. Vismodegib demonstrated similar clinical activity across all patient cohorts, including patients aged $\geq 65$ years. Numerical differences in response rates between cohorts were not considered to be clinically meaningful and were likely due to differences in response criteria, assessment schedule, treatment duration, and length of follow-up in each study.

Patients aged $\geq 65$ years are often considered at greater risk of AEs because of the presence of comorbidities and age-related impairment of organ function [7]. Importantly, the incidence of common chronic conditions in these studies (ERIVANCE BCC and EAS) was generally similar to that in the general population (US Medicare fee-for-service beneficiaries) in both patients aged $\geq 65$ years and younger patients, except for a lower incidence of diabetes $(8-9 \%$ and $4-6 \%$ in

Table 2: Exposure to study treatment

\begin{tabular}{|c|c|c|c|c|c|c|c|c|}
\hline & \multicolumn{4}{|c|}{ ERIVANCE BCC $(N=104)$} & \multicolumn{4}{|c|}{$\operatorname{EAS}(N=119)$} \\
\hline & \multicolumn{2}{|c|}{ laBCC } & \multicolumn{2}{|c|}{$\mathrm{mBCC}$} & \multicolumn{2}{|c|}{ laBCC } & \multicolumn{2}{|c|}{$\mathrm{mBCC}$} \\
\hline & $\begin{array}{c}\geq 65 \text { years } \\
(n=33)\end{array}$ & $\begin{array}{c}<65 \text { years } \\
(n=38)\end{array}$ & $\begin{array}{c}\geq 65 \text { years } \\
(n=14)\end{array}$ & $\begin{array}{c}<65 \text { years } \\
(n=19)\end{array}$ & $\begin{array}{c}\geq 65 \text { years } \\
(n=27)\end{array}$ & $\begin{array}{c}<65 \text { years } \\
(n=35)\end{array}$ & $\begin{array}{c}\geq 65 \text { years } \\
(n=26)\end{array}$ & $\begin{array}{c}<65 \text { years } \\
(n=31)\end{array}$ \\
\hline $\begin{array}{l}\text { Median } \\
\text { total No. } \\
\text { of } 150-\mathrm{mg} \\
\text { capsules } \\
\text { taken, } n \\
\text { (range) }\end{array}$ & $\begin{array}{c}275 \\
(25-564)\end{array}$ & $\begin{array}{c}300 \\
(118-555)\end{array}$ & $\begin{array}{c}276 \\
(19-378)\end{array}$ & $\begin{array}{c}335 \\
(56-500)\end{array}$ & $\begin{array}{c}218 \\
(32-530)\end{array}$ & $\begin{array}{c}143 \\
(41-553)\end{array}$ & $\begin{array}{c}142 \\
(32-581)\end{array}$ & $\begin{array}{c}167 \\
(13-585)\end{array}$ \\
\hline $\begin{array}{l}\text { Median } \\
\text { total } \\
\text { cumulative } \\
\text { dose } \\
\text { (range), g }\end{array}$ & $\begin{array}{c}41 \\
(4-85)\end{array}$ & $\begin{array}{c}45 \\
(18-83)\end{array}$ & $\begin{array}{c}41 \\
(3-57)\end{array}$ & $\begin{array}{c}50 \\
(8-75)\end{array}$ & $\begin{array}{c}33 \\
(5-80)\end{array}$ & $\begin{array}{c}21 \\
(6-83)\end{array}$ & $\begin{array}{c}21 \\
(5-87)\end{array}$ & $\begin{array}{c}25 \\
(2-88)\end{array}$ \\
\hline
\end{tabular}

$\mathrm{BCC}=$ basal cell carcinoma; EAS = expanded access study; laBCC = locally advanced basal cell carcinoma; $\mathrm{mBCC}=$ metastatic basal cell carcinoma; $\mathrm{NA}=$ not applicable. 
Table 3: Investigator-assessed best overall response (efficacy-evaluable patients)

\begin{tabular}{|c|c|c|c|c|c|c|c|c|}
\hline & \multicolumn{4}{|c|}{ ERIVANCE BCC $(N=96)$} & \multicolumn{4}{|c|}{ EAS $(N=95)$} \\
\hline & \multicolumn{2}{|c|}{ laBCC } & \multicolumn{2}{|c|}{$\mathbf{m B C C}$} & \multicolumn{2}{|c|}{ laBCC } & \multicolumn{2}{|c|}{ mBCC } \\
\hline & $\begin{array}{c}\geq 65 \text { years } \\
(n=30)\end{array}$ & $\begin{array}{c}<65 \text { years } \\
(n=33)\end{array}$ & $\begin{array}{l}\geq 65 \text { years } \\
(n=14)\end{array}$ & $\begin{array}{l}<65 \text { years } \\
(n=19)\end{array}$ & $\begin{array}{c}\geq 65 \text { years } \\
(n=24)\end{array}$ & $\begin{array}{c}<65 \text { years } \\
(n=32)\end{array}$ & $\begin{array}{c}\geq 65 \text { years } \\
(n=18)\end{array}$ & $\begin{array}{c}<65 \text { years } \\
(n=21)\end{array}$ \\
\hline $\mathrm{BORR}, n(\%)$ & $14(46.7)$ & $24(72.7)$ & $5(35.7)$ & $10(52.6)$ & $11(45.8)$ & $15(46.9)$ & $6(33.3)$ & $6(28.6)$ \\
\hline$[95 \% \mathrm{CI}]$ & {$[28.3-65.7]$} & {$[54.5-86.7]$} & [12.8-64.9] & {$[28.9-75.6]$} & {$[25.6-67.2]$} & {$[29.1-65.3]$} & {$[13.3-59]$} & [11.3-52.2] \\
\hline Complete response & $8(26)$ & $12(36)$ & 0 & 0 & $2(8)$ & $4(12)$ & $1(6)$ & $1(5)$ \\
\hline Partial response & $6(20)$ & $12(36)$ & $5(36)$ & $10(53)$ & $9(38)$ & $11(34)$ & $5(28)$ & $5(24)$ \\
\hline Stable disease & $11(37)$ & $4(12)$ & $7(50)$ & $8(42)$ & $12(50)$ & $15(47)$ & $9(50)$ & $11(52)$ \\
\hline Progressive disease & $2(7)$ & $4(12)$ & $1(7)$ & $1(5)$ & 0 & 0 & $1(6)$ & $2(10)$ \\
\hline Not evaluable/missing & $3(10)$ & $1(3)$ & $1(7)$ & 0 & $1(4)$ & $2(6)$ & $2(11)$ & $2(10)$ \\
\hline
\end{tabular}

BCCNS = basal cell carcinoma nevus syndrome; $\mathrm{BORR}=$ best overall response rate; $\mathrm{CI}=$ confidence interval; EAS $=$ expanded access study; laBCC = locally advanced basal cell carcinoma; $\mathrm{mBCC}=$ metastatic basal cell carcinoma.

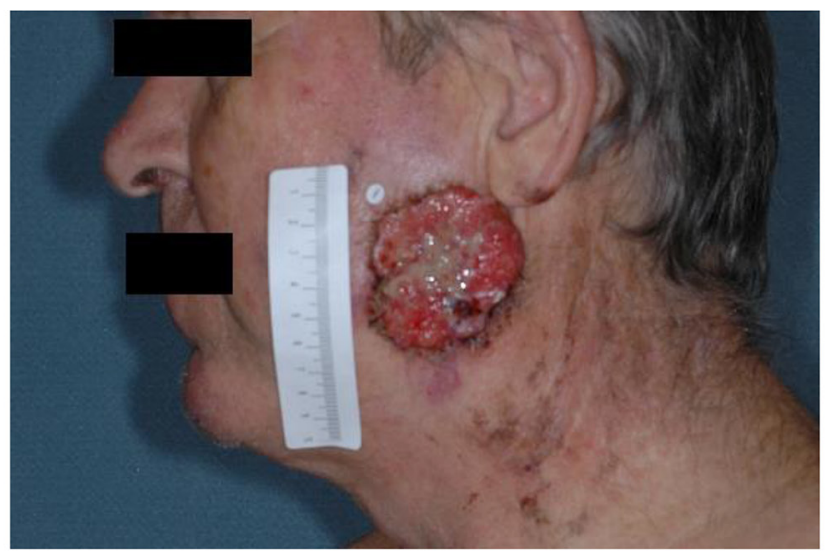

C

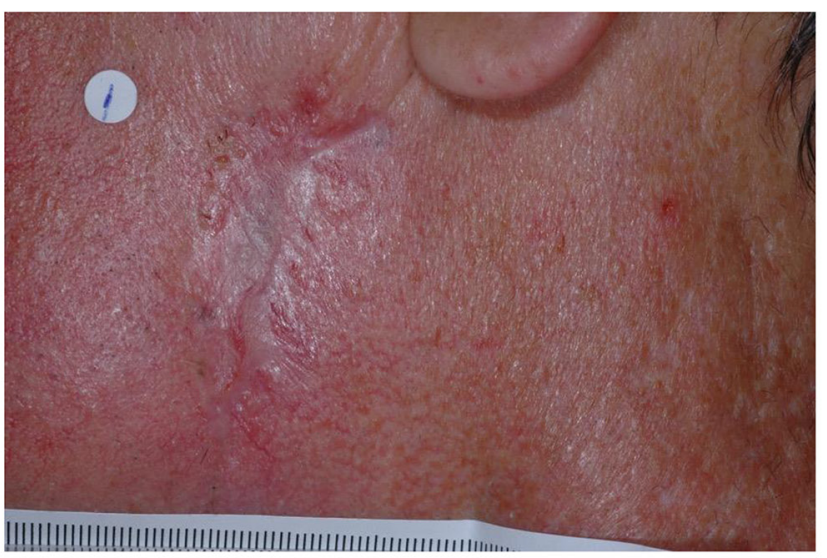

B

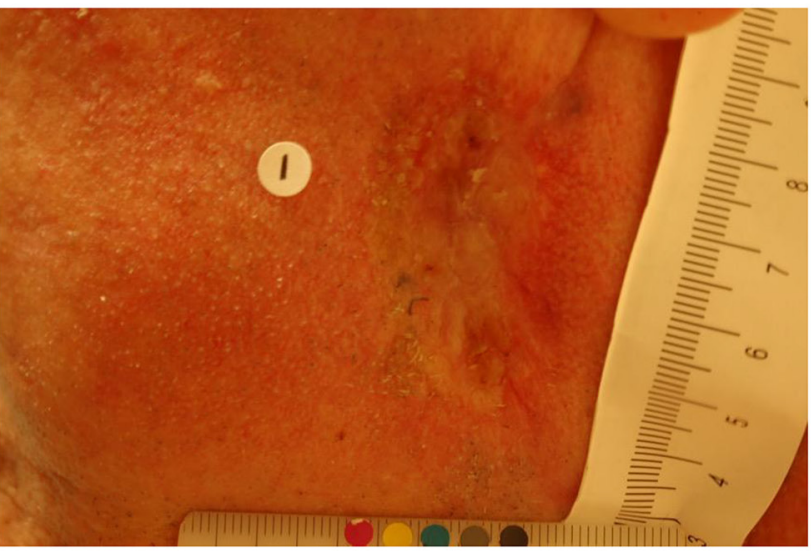

D

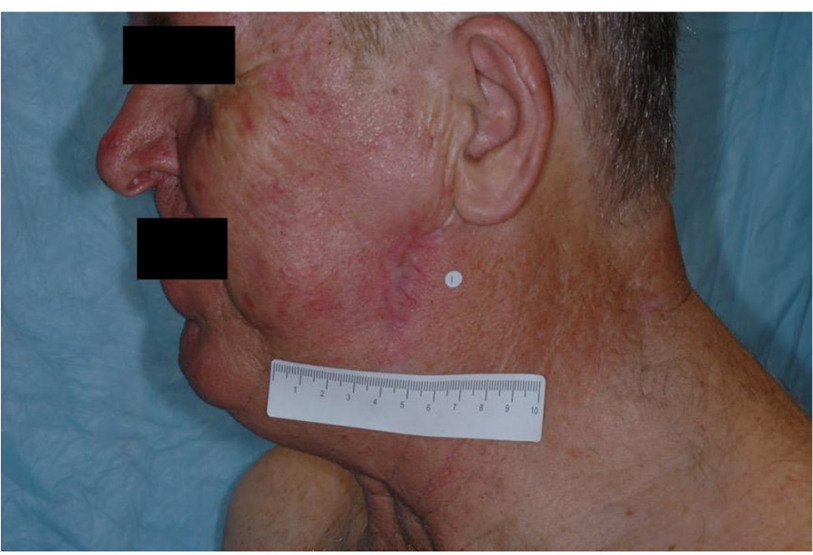

Figure 1: Representative examples of individual patient responses. Patient 1: Single target lesion in a 59-year-old man at screening A. 8 weeks B. 16 weeks C. and 24 weeks D. (Continued). 

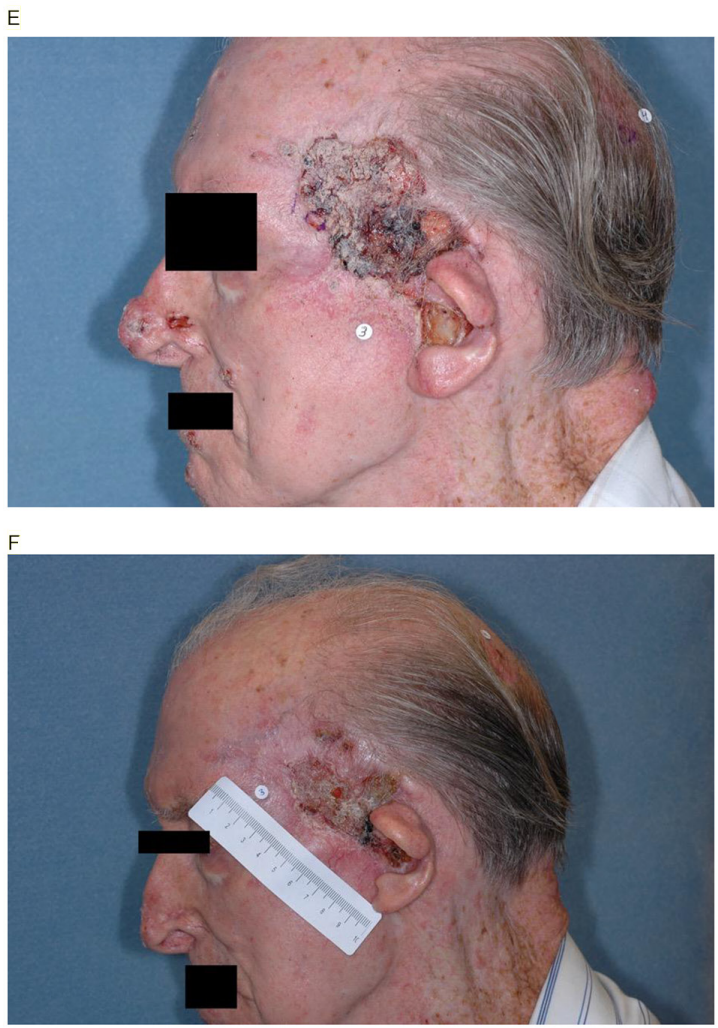
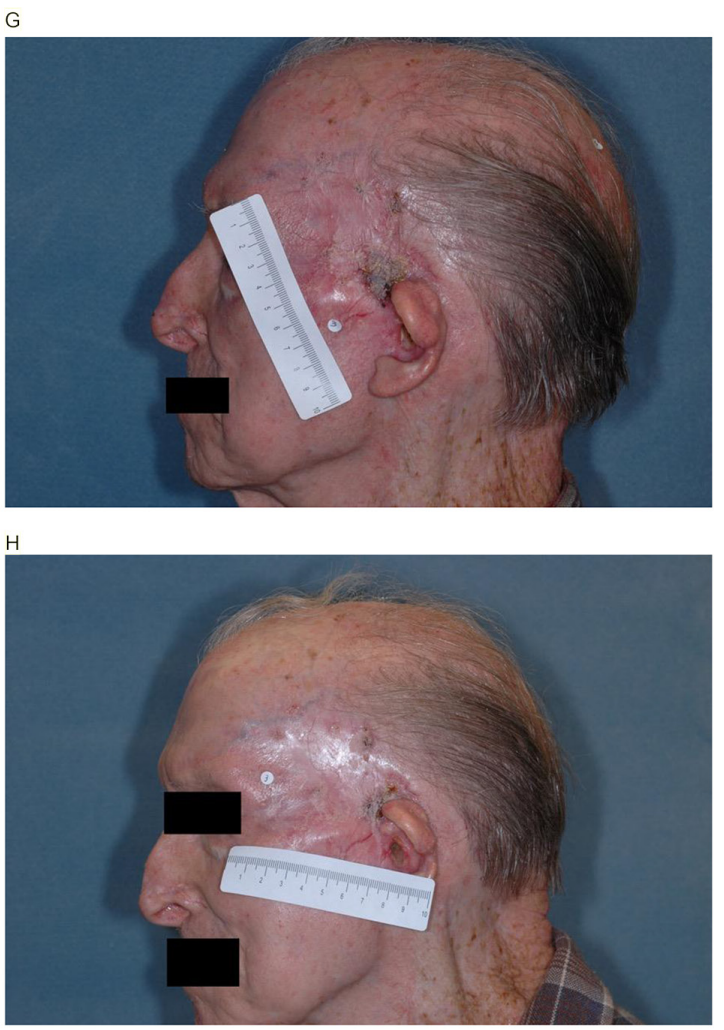

Figure 1: (Continued) Representative examples of individual patient responses. Patient 2: Target lesion on the left temple in an 82-year-old man at screening E. 8 weeks F. 16 weeks $\mathbf{G}$. and 24 weeks $\mathbf{H}$.

Table 4: Selected adverse events

\begin{tabular}{lcccc}
\hline Selected AEs, $\mathbf{n}(\mathbf{\%})$ & \multicolumn{2}{c}{ ERIVANCE BCC $(\boldsymbol{N}=\mathbf{1 0 4})$} & \multicolumn{2}{c}{ EAS $(\boldsymbol{N}=\mathbf{1 1 9})$} \\
\hline & $\begin{array}{c}\mathbf{6 5 5} \text { years } \\
(\boldsymbol{n}=\mathbf{4 7})\end{array}$ & $\begin{array}{c}<\mathbf{6 5} \text { years } \\
(\boldsymbol{n}=\mathbf{5 7})\end{array}$ & $\begin{array}{c}\mathbf{6 5} \text { years } \\
(\boldsymbol{n}=\mathbf{5 3})\end{array}$ & $\begin{array}{c}<\mathbf{6 5} \text { years } \\
(\boldsymbol{n}=\mathbf{6 6})\end{array}$ \\
\hline Any AE & $47(100)$ & $57(100)$ & $52(98)$ & $64(97)$ \\
Grade 3-5 AE & $24(51)$ & $20(35)$ & $13(25)$ & $14(21)$ \\
AE leading to & $7(15)$ & $6(11)$ & $6(11)$ & $1(2)$ \\
discontinuation & $30(64)$ & $41(72)$ & $37(70)$ & $47(73)$ \\
Muscle spasms & $24(51)$ & $29(51)$ & $37(70)$ & $47(73)$ \\
Dysgeusia & $23(49)$ & $43(75)$ & $29(55)$ & $40(61)$ \\
Alopecia & $12(25)$ & $18(32)$ & $9(17)$ & $14(21)$ \\
Nausea & $8(17)$ & $15(26)$ & $14(26)$ & $16(24)$ \\
Diarrhea & $7(15)$ & $5(9)$ & $2(4)$ & $1(2)$ \\
Ageusia & $11(23)$ & $6(11)$ & $5(9)$ & $9(14)$ \\
Constipation & $6(13)$ & $10(18)$ & 0 & $4(6)$ \\
Arthralgia & $23(49)$ & $25(44)$ & $10(19)$ & $9(14)$ \\
Decreased weight & $14(30)$ & $10(18)$ & $7(13)$ & $9(14)$ \\
Decreased appetite & $17(36)$ & $20(35)$ & $10(19)$ & $13(20)$ \\
Fatigue & & &
\end{tabular}

$\mathrm{AE}=$ adverse event; $\mathrm{BCCNS}=$ basal cell carcinoma nevus syndrome; $\mathrm{EAS}=$ expanded access study. 
patients aged $\geq 65$ and $<65$ years, respectively, compared with a prevalence of $27 \%$ and $25 \%$, respectively) [9]. In this analysis, the safety profile of vismodegib in patients aged $\geq 65$ years appeared to be similar to that observed in younger patients. While numerical differences were observed between analytical cohorts, no consistent trends were observed across the 2 trials. These conditions often require treatment with medications known to influence hepatic drug metabolism when co-administered with inhibitors of drug-metabolizing and transporter enzymes $[10,11]$. However, the therapeutic index of vismodegib is broad, with no obvious relationship between exposure and AEs. Furthermore, results of clinical studies show that various cytochrome (CYP2C8, CYP3A4, CYP2C9) substrates and a proton pump inhibitor (rabeprazole) do not meaningfully alter the pharmacokinetic profile of vismodegib $[10,11]$. The similar AE profile and the tumor response in the $<65$ - and $\geq 65$-year-old patient cohorts treated with vismodegib make it reasonable to conclude that vismodegib is safe and effective and may be concomitantly administered with common medications used in patients aged $\geq 65$ years with locally advanced or metastatic BCC.

\section{CONCLUSION}

The results of this analysis suggest that patients aged $\geq 65$ years are likely to experience benefit from vismodegib similar to that for younger patients without any apparent increase in the risk of AEs.

\section{MATERIALS AND METHODS}

\section{Study design}

ERIVANCE BCC (ClinicalTrials.gov number NCT00833417) was an international, multicenter, non-comparative phase 2 study. EAS (SHH4811g, ClinicalTrials.gov number NCT01160250) was a multicenter, open-label, noncomparative expanded access study to provide patients with aBCC who lack satisfactory treatment options access to vismodegib prior to regulatory approval. The EAS was terminated early because of FDA approval of vismodegib. All patients signed written informed consent before enrolling in either study.

\section{Key eligibility criteria}

Key eligibility criteria for the ERIVANCE BCC and EAS studies were similar. Patients with $\mathrm{mBCC}$ were required to have histologic confirmation of distant metastasis. Patients with laBCC were required to have $\geq 1$ lesion measuring $\geq 10 \mathrm{~mm}$, inoperable or surgery contraindicated (e.g., recurrence after $\geq 2$ prior surgeries and curative resection deemed unlikely, or anticipated substantial morbidity and/or deformity from surgery), and prior radiation to $\geq 1$ lesion, unless contraindicated or inappropriate. Other criteria included age $\geq 18$ years, adequate organ function, and Eastern Cooperative Oncology Group performance status $\leq 2$. While the ERIVANCE BCC trial required patients to have measurable disease according to Response Evaluation Criteria in Solid Tumors, version 1.0 (RECIST v1.0) guidelines, the EAS study also allowed enrollment of patients with nonmeasurable disease. Both trials allowed enrollment of patients with BCCNS, as long as all other eligibility criteria were met.

\section{Treatment}

In both studies, all patients received oral vismodegib $150 \mathrm{mg} /$ day until disease progression, intolerable toxicity, patient withdrawal, or study termination.

\section{Assessments}

\section{Efficacy assessments}

For mBCC, response was evaluated according to RECIST v1.0 in both ERIVANCE BCC and EAS. For laBCC, response was assessed according to RECIST v1.0 in the EAS and to a novel composite endpoint $(\geq 30 \%$ reduction in externally visible or radiographic dimensions, or complete resolution of ulceration if present at baseline) in ERIVANCE BCC. Response assessments were performed every 8 weeks in ERIVANCE BCC and every 8-16 weeks in the EAS.

\section{Safety assessments}

Adverse events were assessed on a monthly basis in both trials and graded according to National Cancer Institute Common Terminology Criteria for Adverse events (NCI-CTCAE), version 3.0 in the ERIVANCE trial and NCI-CTCAE version 4.0 in the EAS trial.

\section{Analysis}

All patient data available as of November 26, 2010, for ERIVANCE BCC (primary analysis) and April 23, 2012, for US EAS (final analysis) were included in the analyses. Analytic cohorts for patients aged $\geq 65$ and $<65$ years were created within each trial for comparison using descriptive statistical methods. Data were not pooled across the trials because of the described differences in the schedule and the criteria for assessment of response. Best overall response rate was analyzed in efficacy-evaluable patients, and 95\% CI was computed using the ClopperPearson method.

\section{ACKNOWLEDGMENTS}

Third-party editorial assistance for this manuscript was provided by ApotheCom (San Francisco, CA, USA) and was funded by F. Hoffmann-La Roche Ltd. 


\section{CONFLICTS OF INTEREST}

Alice S. Chang indicates that she is a clinical investigator on clinical trials sponsored by F. HoffmannLa Roche, Ltd., and Genentech. Karl D. Lewis declares no conflict of interest. Sarah T. Arron has received honoraria for advisory boards from F. Hoffmann-La Roche, Ltd., and Leo Pharma; salaries as an investigator from Genentech, Anacor; and Allergan, and salary as a consultant from Portola Pharmaceutical. Michael R. Migden has received honoraria for advisory boards from Genentech, Novartis, and Lilly. James A. Solomon has received honoraria for advisory boards from Genentech and Eli Lilly and has served as an investigator on Genentech trials. Simon Yoo has received honoraria as a consultant for Genentech, AbbVie, and Castle Biosciences and owns stock in Woundcare Technology. Bann-Mo Day is a salaried employee of Genentech. Edward McKenna receives salary and stock/stock options as an employee of Genentech. Aleksandar Sekulic has served on advisory boards for Roche/Genentech (no personal compensation).

\section{FINANCIAL SUPPORT}

This study was supported by F. Hoffmann-La Roche Ltd.

\section{Authors Contributions}

All authors: Acquisition, analysis, and interpretation of data, and revising the manuscript.

\section{REFERENCES}

1. Epstein EH. Basal cell carcinomas: attack of the hedgehog. Nat Rev Cancer. 2008; 8:743-754.

2. Göppner D, Leverkus M. Basal cell carcinoma: from the molecular understanding of the pathogenesis to targeted therapy of progressive disease. J Skin Cancer. 2011; 2011:650258.
3. Sekulic A, Migden MR, Oro AE, Dirix L, Lewis KD, Hainsworth JD, Solomon JA, Yoo S, Arron ST, Friedlander PA, Marmur E, Rudin CM, Chang AL, et al. Efficacy and safety of vismodegib in advanced basal-cell carcinoma. N Engl J Med. 2012; 366:2171-2179.

4. Sachs DL, Marghoob AA, Halpern A. Skin cancer in the elderly. Clin Geriatr Med. 2011; 17:715-738, vii.

5. Farage MA, Miller KW, Berardesca E, Maibach HI. Neoplastic skin lesions in the elderly patient. Cutan Ocul Toxicol. 2008;27: 213-229.

6. Varga E, Korom I, Raskó Z, Kis E, Varga J, Oláh J, Kemény L. Neglected basal cell carcinomas in the 21 st century. J Skin Cancer. 2011; 2011:392151.

7. Pal SK, Katheria V, Hurria A. Evaluating the older patient with cancer: understanding frailty and the geriatric assessment. CA Cancer J Clin. 2010; 60:120-132.

8. Chang AL, Solomon JA, Hainsworth JD, Goldberg L, McKenna E, Day BM, Chen DM, Weiss GJ. Expanded access study of patients with advanced basal cell carcinoma treated with the Hedgehog pathway inhibitor, vismodegib. J Am Acad Dermatol. 2014; 70:60-69.

9. Centers for Medicare and Medicaid Services. National chronic condition charts 2012. http://www.cms.gov/ Research-Statistics-Data-and-Systems/Statistics-Trendsand-Reports/Chronic-Conditions/Maps_Charts.html.

Accessed February 16, 2016.

10. LoRusso PM, Piha-Paul SA, Mita M, Colevas AD, Malhi V, Colburn D, Yin M, Low JA, Graham RA. Co-administration of vismodegib with rosiglitazone or combined oral contraceptive in patients with locally advanced or metastatic solid tumors: a pharmacokinetic assessment of drug-drug interaction potential. Cancer Chemother Pharmacol. 2013; 71:193-202.

11. Malhi V, Colburn D, Tripathi M, Deng Y, Hop C, Dresser M, Chandra P, Graham R. A clinical drug-drug interaction study to evaluate the effect of a proton pump inhibitor, a combined P-gp/CYP3A4 inhibitor, and a CYP2C9 inhibitor on the pharmacokinetics of vismodegib. Presented at: 2014 American Association of Pharmaceutical Scientists Annual Meeting and Exposition; November 2-6, 2014; San Diego, CA. Abstract T3337. 